\title{
LENS CADMIUM, LEAD AND SERUM VITAMIN C, E \& B-CAROTENE IN CATARACTOUS SMOKING PATIENTS
}

\author{
$\mathcal{B Y}$ \\ Soad, M.Mosad; Hossam, M.El-Sayed*; Amr, M.El-Kannishy*; \\ Assad, A.Ghanem*; Azza, A. El-Biomy** and Amany M. Al -Diasty** \\ Departments of Forensic Medicine and Clinical Toxicology; Ophthalmology* and Clinical Pathology**, \\ Faculty of Medicine, Mansoura University, Egypt
}

\begin{abstract}
The present study comprised 60 cataractous male patients aged from 44 - 55 years who attended Ophthalmic Center of Mansoura University. They were categorized into two groups; the first group comprised 15 patients who had never smoked before with minimal exposure to cigarette smoking (served as a control group) while the second group comprised 45 age,body mass index matched smokers. Smokers were classified according to Ferris Smoking Index (packs / day x 365 x number of years of smoking) into light (smoke 1000 packs), moderate (smoke 1000- 6000 packs) and heavy (smoke > 6000 packs) smokers. Blood cadmium and lead concentrations were measured and their levels in the cataractous lens nuclei were also estimated. The levels of some antioxidants such as serum vitamin $C ; E$ and beta carotene were determined. Cadmium had a statistically significant higher concentration in blood and lenses of smokers compared with that of non smokers $(p<0.0001)$. There was a threefold increase in blood cadmium concentration $(9.54 \pm 0.25 \mu \mathrm{g} / \mathrm{dl})$ in heavy smokers and twofold increase in moderate and low smokers (6.87 \pm 0.77 and $6.38 \pm 0.36 \mu \mathrm{g} / \mathrm{dl}$ respectively) while it was $3.37 \pm 0.4 \mu \mathrm{g} / \mathrm{dl}$ in non smokers. There was a significantly high accumulation of cadmium in lenses of cataractous smokers reaching about fourfold increase in heavy smokers $(1.73 \pm 0.05 \mu \mathrm{g} / \mathrm{gm})$ nearly threefold increase in moderate and low smokers $(1.36 \pm 0.08$ and $1.13 \pm 0.05 \mu \mathrm{g} / \mathrm{gm}$ respectively) when compared to that of non smokers $(0.42 \pm 0.11 \mu \mathrm{g} /$ gm). A highly significant elevation of blood lead concentrations and lenses lead was observed in smokers when compared to non smokers. As regard vitamin E, C and beta carotene, a highly significant reduction was observed in smokers when compared with non smokers). There was a highly positive correlation between blood cadmium concentrations and both lens cadmium levels, blood lead concentrations \& lens lead levels in moderate and heavy smokers. A highly negative correlation between blood cadmium concentration and serum Vitamin E and C levels of smokers was also observed. In conclusion, cadmium present in high concentrations among smokers was found to have an important role in cataractogenesis, through induction of oxidative stress as evidenced by reduction of levels of some antioxidant studied in
\end{abstract}


this work such as vitamin E, $C$ and beta carotene. So, education of health care professionals and the public about the cataractogenic effect of cadmium is mandatory. Intake of various antioxidants may be helpful in prevention or reducing the risk of cataract formation. Some of them may even improve vision in some certain cases. Vitamin C and vitamin E could be helpful. Also, Lutein is a carotenoid found in green and leafy vegetables such as kale and spinach, and is available as a supplement. It is potentially helpful in slowing the process of cataract formation.

\section{INTRODUCTION}

Cataract is a major cause of avoidable blindness and visual impairment throughout the world. At least 5 million to 10 million new, visually disabling cataracts occur yearly around the world. The challenges are to prevent or delay cataract formation and to treat that which occurs (Brian and Taylor, 2001).

Although safe and effective technologies are available that could restore normal vision to a large number of those affected, the cataract burden continues to increase annually, because of the backlog of patients to be operated on, and the growing number of cataract cases, due to increased life expectancy. Although surgery is the only effective available treatment option, identifying risk factors may help to establish preventive measures and appropriate strategies at the level of primary or primordial prevention. World Health Report, published in 1998, estimated that there were 19.34 million people who were bilaterally blind (visual acuity $<3$ / 60 in the better eye ) due to age - related cataract and expected to be 40 million people by the year 2025 (WHO,1998).

The position of eye in contact with the outside agents, as environmental pollution makes it a target organ of many systematic diseases, whether contagious or toxic. It is supposed that environmental pollution plays an important role, in etiology of senile cataract. Subsequently the heavy metal cadmium, which may be present in the environment due to pollution, as well as due to smoking could re - enter among causes of cataract (Dodi, 2000).

It was assumed that changes in the cadmium and vitamin $C$ levels in the blood might be responsible for cataractogenesis in the smokers. Although several authors have reported a progressive accumulation of cadmium in senile cataract as brunescence advances; there are few reports on the cadmium contents in the lens tissue of smokers (Racz and Erdohelyi, 1988 ; Foster et al., 2003).

\section{AIM OF THE WORK}

The present study was designed to investigate the association between smoking 
and posterior subcapsular cataract among males by measuring cadmium and lead in the blood and cataractous lenses and to correlate the results with blood cadmium levels and serum levels of vitamin C, E and beta carotene.

\section{SUBJECTS AND METHODS}

This study was conducted on 60 cataractous male patients aged from $44-55$ years who were admitted to Ophthalmic Center of Mansoura University. They were categorized into two groups; the first group comprised 15 non smokers patients with minimal exposure to passive smoking (served as a control group) and the second group comprised 45 smokers with matched ages and body mass index (BMI $=$ weight in $\mathrm{kg}$ divided on double the length in meters). Cataractous smokers were classified according to Ferris Smoking Index (1962) (packs / day x 365 x number of years of smoking) into light, moderate and heavy smokers as follows:

- Light smokers (L): comprised 15 males who smoke 1000 packs.

- Moderate smokers (M): comprised 15 males who smoke 1000- 6000 packs and

- Heavy smokers (H): comprised 15 males who smoke $>6000$ packs (Ferris, 1962).

Thorough history was taken from each patient with special emphasis on age, resi- dence, smoking habit (number of cigarettes smoked per day and the duration of smoking in years), history of diabetes, hypertension, hepatic, renal, urological, thyroid disease and drug or alcohol intake. The clinical profiles for all men participating in this study were similar except for smoking habits.

Inclusion criteria were confined to: I) Only males because it is reported that females are less susceptible to cadmium accumulation than males. II) Those up to a maximum age of 58 years (higher age was avoided as aging itself could decrease vitamin $C$ in lens and cause accumulation of cadmium). III) Those who had nuclear cataract with or without anterior or posterior subcapsular cataract.

Exclusion criteria were: I) Patients who had cortical cataract, II) patients with diabetes, hypertension, hepatic, renal, urological, thyroid diseases, metabolic or systemic disease, III) glaucoma or other ocular diseases, IV) alcoholics and IIV) patients on steroid antihistaminic, tranquilizers or anti-inflammatory drug treatment or any medication that could interfere with their blood element level. General examination was done for each case including body mass index (Height, Weight). Ophthalmic examination for each case including refraction, best - corrected visual acuity, intraocular pressure, slit - lamp biomicroscopy, ophthalmoscopy with special 
emphasis on the type and severity of cataract.

From each participant, $10 \mathrm{ml}$. venous blood were withdrawn from anticubital vein under complete aseptic condition; of which five $\mathrm{ml}$. were added into EDTA containing polypropylene tubes, shacked gently to be used for measurement of cadmium and lead. Lenses extracted by extracapsular method and put in clean dry containers. Both blood and lenses were kept at $4^{\circ} \mathrm{C}$ until assay.

Digestion of blood and lenses were done by wet method of digestion (nitric perchloric acid) according to the method of Vanloon (1985). Analysis of total cadmium and lead was done by the method of Stockwell and Corns (1993) using Perkin Elmer 2380 Atomic Absorption Spectrophotometer (AAS cold steam technique in combination with flow injection system). Preparation of standards and samples was carried out under clean conditions using deionized water. All chemicals and reagents used were of ultra pure reagent grade. All glassware and plasticware were washed three times with deionized water, and then soaked in 20\% nitric acid overnight. After soaking, the glassware was rinsed three times with deionized water and dried. Quality assurance was achieved by measuring blank test solutions. All metal contents were measured on the working standard curve in dupli- cate (variation error should be less than $3 \%)$.

The other five milliliters blood were separated by centrifugation after clotting in water bath to obtain sera for analysis of vitamin C, E, and beta carotene. Serum ascorbic acid was measured by colorimetric method according to Jacob (1990). It was oxidized by copper to form dehydroascorbic acid, which reacts with acidic 2, 4 dinitrophenyle hydrazine to form a red bishydrazone, which is measured at $520 \mathrm{~nm}$. Serum vitamin E and beta carotene were assayed calorimetrically according to the method of Baker \& frank (1968) and Oliver (1980) respectively. It is based on an oxidation reduction reaction following specific elution techniques. Fractions were subjected to the emmeric-Engel procedure in which tocopherol is oxidized to tocopheryl quinine by ferric chloride and ferrous ions in the resultant ferric chloride forming a complex with $\alpha \alpha^{\prime}$-dipyridyl to produce a red colour. Chemicals were product of Sigma (USA).

\section{Statistical analysis :}

Mean $\pm S D$ of the results were compared by using student's t-test (to compare two groups); Chi square $\left(X^{2}\right)$ was used for qualitative data (frequency and proportion). Correlation co-efficiency was used to test association between variables. These statistical analysis were run on an IBM compatible personal computer by 
using Statistical Package for Social Scientists (SPPS) for windows 11 (SPSS Inc., Chicago, IL , USA).

\section{RESULTS}

All heavy smokers' cataractous patients; $76.67 \%$ of moderate smokers; 49.70 of light smokers and $20 \%$ of non smokers lived in urban areas as shown in table (1). Severity of cataract was associated with heavy smoking; present in 13 cases out of 15 while in non smokers, cataract was mild in 8 patients and moderate in 7 cases. There was insignificant variation as regard body mass index.

Comparison between different groups showed that cadmium had a statistically significant higher concentration in blood and lenses of smokers compared with that of non smokers $(p<0.0001)$ as shown in table (2). There was a threefold increase in blood cadmium concentration $(9.54 \pm 0.25$ $\mu \mathrm{g} / \mathrm{dl}$ ) of heavy smokers and nearly twofold increase in moderate and low smokers $(6.87 \pm 0.77$ and $6.38 \pm 0.36$ respectively) while it was $3.37 \pm 0.4 \mu \mathrm{g} / \mathrm{dl}$ in non smokers.

There was a significantly high accumulation of cadmium in lenses of cataractous smokers reaching about fourfold increase in heavy smokers $(1.73 \pm 0.05 \mu \mathrm{g} / \mathrm{gm})$ and nearly threefold increase in moderate and low smokers $(1.36 \pm 0.08$ and $1.13 \pm 0.05$ $\mu \mathrm{g} / \mathrm{gm}$ respectively) when compared to that of non smokers $(0.42 \pm 0.11 \mu \mathrm{g} / \mathrm{gm})$. A highly significant elevation of blood lead concentrations and lenses lead was observed in smokers when compared to non smokers as shown in Table (3).

As regard serum vitamin $\mathrm{E}, \mathrm{C}$ and beta carotene, a highly significant decrease was observed in smokers when compared with non smokers as shown in table (2). Table (4) revealed a highly positive correlation between blood cadmium concentrations and both lens cadmium levels, blood lead concentrations and lens lead level in moderate and heavy smokers. A highly negative correlation between blood cadmium concentrations and both Vitamin $\mathrm{E}$ and $\mathrm{C}$ levels of smokers was also observed.

\section{DISCUSSION}

Human can be exposed to toxic metals such as cadmium and lead which arise from widespread sources, including cigarette smoke which contains cadmium in a high concentration (Wong et al., 2000), air pollution, leaching of landfills, industrial waste, emissions from fossil fuels, fertilizers and corrosion of plumbing (AMAP, 2000). Cadmium has a biological half life in humans up to 30 years and large amounts of it have been detected in lenses of chronic smokers who also exhibit early cataract formation ((Ramakrishnan et al., 1995). Increased cadmium levels have 
been reported in cataract versus clear human lenses. Rouhiainen et al. (1996) found an association between low plasma vitamin $\mathrm{E}$ concentration and progression of early cortical lens opacities. In a study by Hawse et al., (2006) no differences were detected in levels of cadmium and lead among young, middle aged and old healthy lenses. Cadmium and lead were not detected in clear analyzed lenses suggesting that increased cadmium levels were specific to cataractous lenses. Since, intact non cataractous lenses are not available, the present study aimed to compare the concentrations of cadmium and lead in blood and lenses of cataractous smokers patients using cataractous non smokers as a control.

In the present study, there were high concentration of cadmium in the blood of smokers than in non smokers. This confirmed the finding of previous workers in the field. This increase was larger in heavy smokers due to chronic smoking and also higher age group as cadmium is accumulated with advancing of age. The value reported in the literature is different-for instance, $0.3-1.2 \mu \mathrm{g} / \mathrm{L}$ (Lyyengar and Woittiez, 1988) in non smokers and 0.6-3.9 $\mu \mathrm{g} / \mathrm{L}$ for smokers. In view of ecological and environmental condition, differences in the cadmium content of cigarettes, number smoked, and above all, absence of a homeostatic mechanism for cadmium in the living system, such variations are bound to occur and comparison of results has to be made in the studies in the particular centre. In Mansoura, a study by Mortada et al. (2002) found that blood cadmium concentration was $2.67 \pm 1.12$ in smokers and $1.37 \pm 0.45 \mu \mathrm{g} / \mathrm{dL}$ among non smokers. Another study by Mosad et al. (2004) found this concentration to be $3.38 \pm 0.42$ in non smokers; $5.80 \pm 0.54$ in light smokers; $6.90 \pm 0.78$ in moderate smokers and $8.95 \pm 0.73 \mu \mathrm{g} / \mathrm{dL}$ in heavy smokers.

Toxic metals are known to be associated with cell death, oxidative stress and lens cataract (Hawse et al., 2006). In the present study, there was a significantly high accumulation of cadmium in lenses of cataractous smokers reaching fourfold increase in heavy smokers $(1.73 \pm 0.05 \mu \mathrm{g} / \mathrm{gm})$ nearly threefold increase in moderate and low smokers $(1.36 \pm 0.08$ and $1.13 \pm 0.05 \mu \mathrm{g} /$ gm respectively) when compared to that of non smokers $(0.42 \pm 0.11 \mu \mathrm{g} / \mathrm{gm})$. In agreement with this result, increased cadmium levels have been demonstrated in cataractous versus clear human lenses. Smoking over a pack of cigarettes a day increases cataract risk by $205 \%$ compared to non smoking at all in men. Quitting smoking alone, without detoxification, however, does not appear to completely eliminate the risk. Former smokers showed a $45 \%$ elevated risk of posterior subcapsular cataracts in men and risk of cataract does not decrease even 10 years 
after quitting (Lindblad et al., 2005). Swartwout (2002) reported that cadmium is 2 to 3 times higher in lenses with cataracts than in clear lenses of the same age.

Cadmium may hasten cataractogenesis by various mechanisms. It may directly interact with lens proteins and denature them (Ramakrishnan et al., 1995). Normally it bounds to low molecular weight proteins, the metallothioneins in the kidneys, liver, and the eye lens and also red cell hemoglobin. There is also free cadmium in blood plasma (Bhattacharyya et al., 1988). It is likely that as the concentration of cadmium increases in blood, the hemoglobin, bounds cadmium, the hemoglobin might lose its full power of delivery of oxygen to tissues including ocular structures. This would mean decrease ATP production and availability of energy. Also cadmium is known to displaces zinc and copper (Preston, 1991) in the body affecting their homeostasis of blood and copper containing protein such as ceruloplasmin and enzymes such as superoxide dismutase and cytochrome a 3. These enzymes are antioxidants, resulting in oxidant damage to the lens of eye (Sahelian, 2006) resulting in lowering of circulating nutrients. Cadmium decreases the bioavailability of selenium and this may affect the biosynthesis of glutathione peroxidase. By a decrease in antioxidants such as ceruloplasmin, superoxide dismutase, and glutathione peroxidase, the defense against oxidative dam- age could be weakened by accumulation of cadmium (Ramakrishnan et al., 1995). There is a growing consensus that smoking increases the risk of nuclear cataract and no association has been reported for cortical cataract (McCarty et al., 1999).

Cadmium and lead in smoke condensates generate long lived reactive oxygen species. These might cause oxidative stress that results in oxidative deterioration of biological macromolecules leading to oxidative damage to the lens and production of cataract (Balasubramanian et al., 1993). Cadmium deplets glutathione and protein - bound sulfhydryl resulting in enhanced production of reactive oxygen species (ROS) endogenously such as superoxide hydroxyl radicals and hydrogen peroxide through photodynamic action. These ROS result in increased lipid peroxidation and enhanced intracellular damage, DNA damage, altered gene expression and apoptosis. Enhanced production of nuclear factor - Kappa B and activation of protein kinase C occur (Stohs et al., 2000). This effect would depend on the amount of such photoactive material in the lens and is therefore thought to be dose - dependent on the heaviness and period of smoke inhalation as evidenced in the present study (Tables 2, 3). This oxidative stress by smoke helps accumulation of metals such as cadmium and iron and reduces the level of vitamin $C$ in the lens and blood of smokers. Oxidative stress 
occurs through a metal - catalyzed fenton reaction that produces ROS and by modulating the role of metallothioneins.

It is known that heavy metal ions such as lead can precipitate blood and body proteins (Marklund, 1986). Lead accumulation in body can result from pollution. Lead was not detected in normal lenses while it was found in cataractous lenses in many studies (Racz and Erdohelyi, 1988; Shukla et al., 1996; Cekic,1998).The observed higher concentration of lead in lenses of smokers in the present work is consistent with results of Cekic (1998). Cadmium accumulation from cigarette smoke may possibly increase the absorption of lead and may trigger accumulated lead in lens. Lindblad et al. (2005) reported that increased intensity of smoking is associated with increased risk of cataract.

In the present study, there was a highly significant negative correlation between serum vitamin $C$ and beta carotene levels and blood cadmium concentration in smokers but not in non smokers. In accordance, Christen et al. (1992) reported depletion of vitamin $C$ in cases of cataract. Being an antioxidant, vitamin $\mathrm{C}$ quenches the oxygen free radicals produced in the lens (Ramakrivishnan et al., 1995). In its deficiency, oxidant challenge may get the upper hand and could cause oxidation of membrane proteins and lipids. Shiraishi, et al. (1993) stated that ascorbic acid (vita- $\min$ C) pretreatment decreases the toxicity of cadmium in the rat without marked modifying cadmium toxicokinetics or markedly stimulating metallothionein synthesis.

Deficiency of vitamin E is also reported to be caused by increased blood cadmium concentration as observed in the present study (Table 4). In accordance Avunduk et al. (1999) reported that vitamin $\mathrm{E}$ has a protective effect on smoke exposed rat lens. Partial relief of the condition by administration of antioxidant vitamin $\mathrm{E}$ and the iron chelator deferoxamine may be beneficial (Avunduk et al., 1999). It binds to sulfhydryl groups, thus potentially deactivating antioxidant functions as well as the $\mathrm{Na}+, \mathrm{K}+-$ ATP ase pump. Cadmium and lead can origenate from cigarette smoke, which has been shown to cause cataracts. Oral or intravenous chelation with EDTA or vitamin C may be beneficial to help eliminate heavy metal accumulations. Lead causes changes in the cells of eye's lens that lead to its clouding (Schaumberg et al., 2004).

In conclusion, accumulation of cadmium from smoking and other sources in lens was associated with nuclear cataract. It may hasten cataractogenesis directly or by inducing oxidative stress as evidenced by reduction of levels of some antioxidant studied in this work such as vitamins E, C and beta carotene. As the present results 
proved increased prevalence of cataract among heavy smokers, since smoking is one of the relatively few known modifiable risk factors associated with cataract, an effective antismoking program and awarness programs should extend to schools. Educating about the ill effects of tobacco smoking may go a long way in promoting healthy behavior among the general population, in particular the younger generation, with a view toward reducing tobacoo - related ailments, including cataract. Also education of health care professionals at all levels and the public about the cataractogenic effect of cadmium is mandatory.

Various antioxidants may be helpful in prevention or reducing the risk of cataract formation. Some may even improve vision in some certain cases so vitamin $C$, vita$\min \mathrm{E}$ and Lutein (is a carotenoid found in green and leafy vegetables such as kale and spinach, and is available as a supplement) are potentially helpful in slowing the process of cataract formation. 
Table (1) : Patient's characteristics.

\begin{tabular}{|c|c|c|c|c|c|}
\hline \multirow{2}{*}{ Parameters } & \multirow{2}{*}{$\begin{array}{c}\text { Nonsmokers } \\
\quad(n=15)\end{array}$} & \multicolumn{3}{|c|}{ Smokers $(n=45)$} & \multirow{2}{*}{$\begin{array}{c}\text { Statistical } \\
\text { analysis }\end{array}$} \\
\hline & & $\begin{array}{c}\text { Light } \\
(\mathrm{n}=15)\end{array}$ & $\begin{array}{c}\text { Moderate } \\
(\mathrm{n}=15)\end{array}$ & $\begin{array}{l}\text { Heav y } \\
(n=15)\end{array}$ & \\
\hline Age in years: Mean \pm SD & $53.40 \pm 3.47$ & $55.00 \pm 4.08$ & $49.80 \pm 5.75$ & $56.70 \pm 1.42$ & $\begin{array}{l}\mathrm{F}=5.43 \\
\mathrm{P}=0.044^{*}\end{array}$ \\
\hline $\begin{array}{ll}\text { Residence: } & \text { Rural } \\
\mathbf{n}(\%) & \\
& \text { Urban }\end{array}$ & $\begin{array}{l}12(80) \\
3(20)\end{array}$ & $\begin{array}{l}8(50.3) \\
7(49.7)\end{array}$ & $\begin{array}{c}5(33.33) \\
10(76.67)\end{array}$ & $\begin{array}{c}0 \\
15(100)\end{array}$ & $\begin{array}{l}X 2=0.003 \\
P=0.001 * *\end{array}$ \\
\hline BMI $\left(\mathrm{Kg} / \mathrm{m}^{2}\right):$ Mean \pm SD & $30.9 \pm 2.52$ & $29.82 \pm 2.52$ & $27.62 \pm 9.22$ & $30.71 \pm 2.37$ & $\begin{array}{l}F=1.01 \\
P=0.40\end{array}$ \\
\hline $\begin{array}{lc}\text { Severity of cataract: } \\
\text { Mild } \quad+\quad \mathrm{n}(\%) \\
\text { Moderate } & ++ \\
\text { Severe } & +++ \\
& ++++\end{array}$ & $\begin{array}{c}8(50.30) \\
7(49.70) \\
0 \\
0\end{array}$ & $\begin{array}{c}2(10.50) \\
13(89.50) \\
0 \\
0\end{array}$ & $\begin{array}{c}4(29.70) \\
8(50.30) \\
3(20.00) \\
0\end{array}$ & $\begin{array}{c}0 \\
0 \\
2(10.50) \\
13(89.50)\end{array}$ & $\begin{array}{l}\mathbf{F}=5.43 \\
P=0.044 *\end{array}$ \\
\hline
\end{tabular}

F : One Way Annova test

*Significant at $\mathbf{P} \leq 0.05$

$\mathrm{X}^{2}:$ Chi square test Insignificant at $\mathbf{P}>\mathbf{0 . 0 5}$
**Highly significant at $\mathrm{P} \leq 0.001$

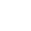

Table (2): Estimated parameters in the cataractous patients.

\begin{tabular}{|c|c|c|c|c|}
\hline \multirow[b]{2}{*}{ Parameters } & \multirow[b]{2}{*}{$\begin{array}{c}\text { Non } \\
\text { smokers } \\
\text { N (n=15) }\end{array}$} & \multicolumn{3}{|c|}{ Smokers $(n=45)$} \\
\hline & & $\begin{array}{l}\text { Light (L) } \\
(n=15)\end{array}$ & $\begin{array}{l}\text { Moderate (M) } \\
\quad(\mathbf{n}=\mathbf{1 5})\end{array}$ & $\begin{array}{l}\text { Heavy }(\mathbf{H}) \\
\quad(n=15)\end{array}$ \\
\hline $\begin{array}{l}\text { Blood cadmium conc. }(\mu \mathrm{g} / \mathrm{dl}) \\
\qquad \begin{array}{l}\text { Range } \\
\text { Mean } \pm \mathrm{SD}\end{array}\end{array}$ & $\begin{array}{l}3.70-2.76 \\
3.37 \pm 0.40\end{array}$ & $\begin{array}{l}5.50-6.59 \\
6.38 \pm 0.36\end{array}$ & $\begin{array}{c}6.00-7.78 \\
6.87 \pm 0.77\end{array}$ & $\begin{array}{l}8.92-9.82 \\
9.54 \pm 0.25\end{array}$ \\
\hline $\begin{array}{l}\text { Lens cadmium conc. }(\mu \mathrm{g} / \mathrm{gm}) \\
\qquad \begin{array}{l}\text { Range } \\
\text { Mean } \pm \mathrm{SD}\end{array}\end{array}$ & $\begin{array}{c}0.22-0.58 \\
0.42 \pm 0.11\end{array}$ & $\begin{array}{c}1.00-1.18 \\
1.13 \pm 0.05\end{array}$ & $\begin{array}{l}1.20-1.46 \\
1.36 \pm 0.08\end{array}$ & $\begin{array}{l}1.65-1.79 \\
1.73 \pm 0.05\end{array}$ \\
\hline $\begin{array}{l}\text { Blood lead conc. }(\mu \mathrm{g} / \mathrm{dl}) \\
\qquad \begin{array}{l}\text { Range } \\
\text { Mean } \pm \mathrm{SD}\end{array}\end{array}$ & $\begin{array}{l}12.03-12.92 \\
12.23 \pm 0.26\end{array}$ & $\begin{array}{c}13.00-14.26 \\
13.52 \pm 0.42\end{array}$ & $\begin{array}{c}14.00-15.2 \\
14.66 \pm 0.36\end{array}$ & $\begin{array}{c}16.45-20.25 \\
18.71 \pm 1.31\end{array}$ \\
\hline $\begin{array}{l}\text { Lens lead conc. }(\mu \mathrm{g} / \mathrm{gm}) \\
\qquad \begin{array}{l}\text { Range } \\
\text { Mean } \pm \mathrm{SD}\end{array}\end{array}$ & $\begin{array}{c}3.08-3.82 \\
3.37 \pm 0.30\end{array}$ & $\begin{array}{l}3.56-5.52 \\
4.28 \pm 0.62\end{array}$ & $\begin{array}{l}5.16-5.69 \\
5.37 \pm 0.16\end{array}$ & $\begin{array}{l}6.56-7.92 \\
7.64 \pm 0.39\end{array}$ \\
\hline $\begin{array}{l}\text { Serum vitamin E level }(\mu \mathrm{g} / \mathrm{dl}) \\
\text { Range } \\
\text { Mean } \pm \mathrm{SD}\end{array}$ & $\begin{array}{l}9.4-10.30 \\
9.82 \pm 0.31\end{array}$ & $\begin{array}{c}3.8-5.6 \\
4.61 \pm 0.61\end{array}$ & $\begin{array}{c}3.2-6.00 \\
4.00 \pm 0.89\end{array}$ & $\begin{array}{l}2.00-2.50 \\
2.09 \pm 0.15\end{array}$ \\
\hline $\begin{array}{l}\text { Serum vitamin C level }(\mathrm{mg} / \mathrm{dl}) \\
\text { Range } \\
\text { Mean } \pm \mathrm{SD}\end{array}$ & $\begin{array}{l}1.00-1.30 \\
1.14 \pm 0.11\end{array}$ & $\begin{array}{c}0.80-0.90 \\
0.84 \pm 0.05\end{array}$ & $\begin{array}{c}0.40-0.70 \\
0.54 \pm 0.11\end{array}$ & $\begin{array}{c}0.10-0.35 \\
0.21 \pm 0.08\end{array}$ \\
\hline $\begin{array}{l}\text { Serum beta carotene level }(\mu \mathrm{g} / \mathrm{dl}) \\
\text { Range } \\
\text { Mean } \pm \text { SD }\end{array}$ & $\begin{array}{c}56.00-73.00 \\
64.20 \pm 5.18\end{array}$ & $\begin{array}{c}40.00-48.00 \\
43.40 \pm 2.88\end{array}$ & $\begin{array}{l}30.00-38.00 \\
33.10 \pm 3.35\end{array}$ & $\begin{array}{r}12.00-35.00 \\
17.90 \pm 6.56\end{array}$ \\
\hline
\end{tabular}


Table (3): Student $t$ test for statistical comparison between the different groups of cataract ous patients as regards the estimated parameters.

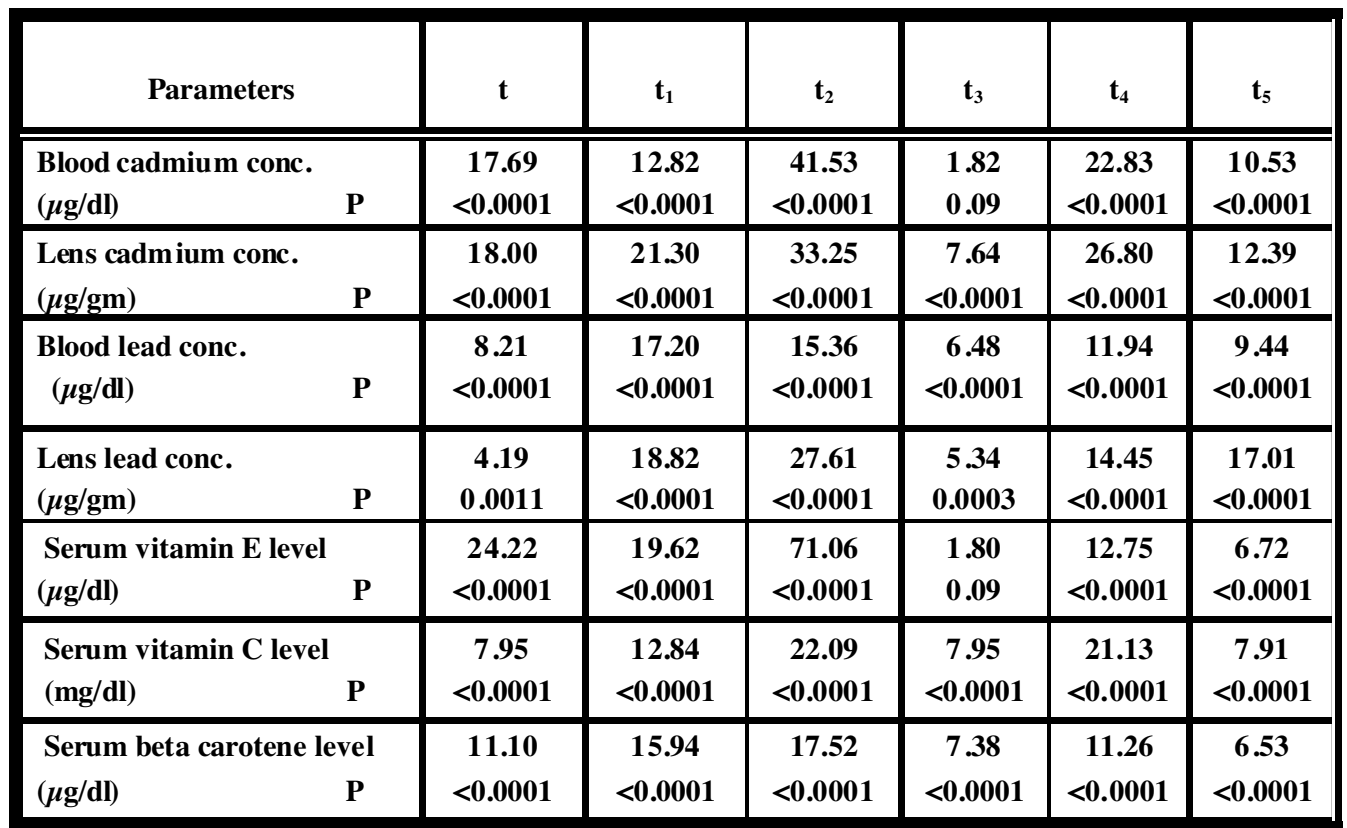

t: between $N \& L \quad t_{1}$ : between $N \& M \quad t_{2}:$ between $N \& H \quad$ Highly significant at $P<0.001$

$t_{3:}$ between $M \& L \quad t_{4}$ : between $H \& L \quad t_{5}$ : between $M \& H$

Table (4): Correlation co-efficient values between blood cadmium concentrations and the studied parameters.

\begin{tabular}{|c|c|c|c|c|c|}
\hline \multirow{2}{*}{\multicolumn{2}{|c|}{ Parameters }} & \multicolumn{4}{|c|}{ Blood cadmium concentrations $(\mu \mathrm{g} / \mathrm{dl})$} \\
\hline & & Non smokers & Low smokers & Moderate smokers & Heavy smokers \\
\hline $\begin{array}{l}\text { Lens cadmium conc. } \\
(\mu \mathrm{g} / \mathrm{gm})\end{array}$ & $\begin{array}{l}\mathbf{r} \\
\mathbf{P}\end{array}$ & $\begin{array}{r}+0.352 \\
0.025\end{array}$ & $\begin{array}{l}+0.835 \\
0.0001\end{array}$ & $\begin{array}{r}+0.369 \\
0.001\end{array}$ & $\begin{array}{l}+0.884 \\
0.0001\end{array}$ \\
\hline $\begin{array}{l}\text { Blood lead conc. } \\
(\mu \mathrm{g} / \mathrm{dl})\end{array}$ & $\begin{array}{l}\mathbf{r} \\
\mathbf{P}\end{array}$ & $\begin{array}{c}+0.294 \\
0.269\end{array}$ & $\begin{array}{c}+0.048 \\
0.926\end{array}$ & $\begin{array}{c}+0.417 \\
0.001\end{array}$ & $\begin{array}{c}+0.454 \\
0.001\end{array}$ \\
\hline $\begin{array}{l}\text { Lens lead conc. } \\
(\mu \mathrm{g} / \mathrm{gm})\end{array}$ & $\begin{array}{l}\mathbf{r} \\
\mathbf{P}\end{array}$ & $\begin{array}{c}+0.132 \\
0.388\end{array}$ & $\begin{array}{r}+0.084 \\
0.926\end{array}$ & $\begin{array}{r}+0.693 \\
0.0001\end{array}$ & $\begin{array}{l}+0.641 \\
0.0001\end{array}$ \\
\hline $\begin{array}{l}\text { Vitamin E level } \\
(\mu \mathrm{g} / \mathrm{dl})\end{array}$ & $\begin{array}{l}\mathbf{r} \\
\mathbf{P}\end{array}$ & $\begin{array}{r}-0.234 \\
0.194\end{array}$ & $\begin{array}{r}-0.683 \\
0.0001\end{array}$ & $\begin{array}{l}-0.712 \\
0.0001\end{array}$ & $\begin{array}{r}-0.830 \\
0.0001\end{array}$ \\
\hline $\begin{array}{l}\text { Vitamin C level } \\
(\mathrm{mg} / \mathrm{dl})\end{array}$ & $\begin{array}{l}\mathbf{r} \\
\mathbf{P}\end{array}$ & $\begin{array}{r}+0.126 \\
0.138\end{array}$ & $\begin{array}{l}-0.607 \\
0.0001\end{array}$ & $\begin{array}{r}+0.427 \\
0.0001\end{array}$ & $\begin{array}{l}-0.628 \\
0.0001\end{array}$ \\
\hline $\begin{array}{l}\text { Beta carotene level } \\
(\mu \mathrm{g} / \mathrm{dl})\end{array}$ & $\begin{array}{l}\mathbf{r} \\
\mathbf{P}\end{array}$ & $\begin{array}{r}-0.034 \\
0.836\end{array}$ & $\begin{array}{r}-0.209 \\
0.194\end{array}$ & $\begin{array}{r}-0.323 \\
0.015\end{array}$ & $\begin{array}{l}-0.21 \\
0.194\end{array}$ \\
\hline
\end{tabular}

Highly significant at $P<0.001$ 


\section{REFERENCES}

AMPA (2000) : Artic Monitoring and Assessment Program. Heavy metals AMPA Report of Issues of concern AMPA Oslo, Norway.

Avunduk, A. M.; Yardimci, S. and Avunduk, M. C. (1999) : Cadmium and iron accumulation in rat lens after cigarette smoke exposure and the effect of vitamin E (alpha - tocopherol) treatment. Curr. Eye Res., 8(6): 403 - 407.

Baker, H. and Frank, O. (1968) : Clinical Vitaminology, Wiley New York, 172.

Balasubramanian, D.; Shalini, V. K.; Luthra, M.; Rao, S. H. N. and Basti, S. (1993) : Molecular epidemiology of the smoke cataract connection. Oxidant stress mechanism. Invest. Ophthalmol. Vis. Sci., 2925.

Bhattacharyya, M. H.; Whelton, B. F. D.; Stern, P. H. and Peterson, D. P. (1988): Cadmium accelerates bone loss in ovariectomized mice and fatal rat limb bones in culture. Proc. Natl. Acad. Sci., 58: 87618764 .

Brian, G. and Taylor, H. R. (2001) : Cataract blindness; Challenges for The 21 st Century. Bull. World Health Org., 79: $249-256$.
Cekic, O. (1998) : Effect of cigarette smoking on copper, lead and cadmium accumulation in human lens. British Journal of Ophthalmology, 82: 186 - 188.

Christen, W. G.; Manson, J. E. and Seddon, J. M. (1992) : A prospective study of cigarette smoking and risk of cataract in men. JAMA, 268: 989 - 993.

Dodi, P. L. (2000) : Plasma levels of vitamins and minerals and lens mineral concentrations in normal and senile cataract in dogs. Universiya di Parma- Facolta di Medicina Veterinaria- Annali.

Ferris, B. G. (1962) : Am. Rev. Resp. Dis., 56:165. Quoted from Amr, M. M.; Aboun, M. A. and El-Batanouny, M. M. (1982) : "Respiratory diseases among workers in printing industry in Egypt". Egyptian J. Chest Dis. Tuber., 25: 27.

Foster, P. J.; Wong, T. Y. and Machin, D. (2003) : Risk factor for nuclear, cortical, and posterior subcapsular cataracts in the Chinase population of Singapore. Br. J. Ophthalmol., 78: 1112 - 1120.

Hawse, J. R.; Padaonkar, V. A.; Levernz, V. R.; Marc Kantoro, S. E. and Giblin, F. J. (2006) : The role of metallothionein II a in defending lens epithelial cell against cadmium and TBHP induced oxidative stress. Mol. Vis., 12 : 342 349. 
Jacob, R. A. (1990) : Assessment of human vitamin C status. J. Nutr. ; 120 (115): 1480 - 1485.

\section{Lindblad, B. E.; Hakansson, N.;} Svensson, H.; Philipson, B. and Wolk, A. (2005) : Intensity of smoking and smoking cessation in relation to risk of cataract extraction : A prospective study of women. Am. J. Epidemiol., 162 (1) : 73 79.

Lyyengar, G. V. and Woittiez, J. (1988) : Trace elements in human specimens; evaluation of literature data to identify reference value. Clin. Chem., 34: 474 481.

Marklund, S. L. (1986) : Superoxide dismutase in human tissue cells and extracellular fluids, clinical implication. Free radicals aging and degenerative disease. New York Alan R Liss, 509.

McCarty, C. A.; Mukesh, B. N. and Fu, C. L. (1999) : The epidemiology of cataract in Australia. Am. J. Ophthalmol., 128: 446 $-465$.

Mortada, W. I.; Sobh, M. A.; El - Defrawy, M. M. and Farahat, S. E. (2002) : Reference intervals of cadmium, lead and mercury in blood, urine, hair and nails among residents in Mansoura City, Nile Delta, Egypt. Environmental Research, Section A 90: 104-110.
Mosad, S. M.; Al-Emam, A. M.; Mostafa, M. E.; Abou Hashem, E. M. and Al Emam, A. M. (2004) : Early markers of nephrotoxicity in cigarette smokers. Accepted for publication in Annual Conference of Mansoura Faculty of Medicine.

Oliver, L. K. (1980): Colorimetric analysis of vitamin A and Carotene. Method Enzymol., 67: 199 - 203.

Preston, A. M. (1991) : Cigarette smoking - nutritional implications. Prog. Food Nutr. Sci., 15: 183 - 217.

Racz, P. and Erdohelyi, A. (1988) : Cadmium, lead and copper concentrations in normal and senile cataractous human lenses. Ophthalmic Res., 20 : 10 13.

Ramakrishnan, S.; Sulochana, T.; Abdul Rahim, A.; Lakshmi, M. and Arunagiri, K. (1995) : Smoking of beedies and cataract: Cadmium and vitamin $C$ in the lens and blood. British Journal of Ophthalmology, 79: 202 - 206.

Rouhiainen, P.; Rouhiainen, $H$. and Salonen, I. (1996) : Association between low plasma vitamin E concentration and progression of early cortical lens opacities. Am. J. Epidemiol., 144: 496 - 500.

Sahelian, R. (2006) : Cadmium exposure aggrevates mortality more in women 
than in men. Int. J. Environ. Health Res., 16 (4): 273 - 279.

Schaumberg, D. A.; Mendes, F.; Balaram, M.; Dana, M. R.; Sparrow, D. and Hu, H. (2004) : Accumulated lead exposure and risk of age - related cataract in men. JAMA, 292 (22): 2750 - 2754.

Shiraishi, N.; Uno, H. and Waalkes, M. P. (1993) : Effect of L - ascorbic acid pretreatment on cadmium toxicity in the male Fisher rat. Toxicology, 85 (2-3): 85 100.

Shukla, N.; Moitra, J. K. and Triverdi, R. C. (1996) : Determination of lead, zinc, potassium, calcium, copper and sodium in human cataract lenses. Sci. Total Environ, 181: 161 - 165.

Stockwell, P. B. and Corns, W. T. (1993) : The role of Atomic Fluorescence Spectrometry in the automatic environmental monitoring of trace element analysis. J. Automatic Chem., 15: 79 - 84.

Stohs, S. J.; Bagchi, D.; Hassoun, E. and Bagchi, M. (2000) : Oxidative mecha- nisms in the toxicity of chromium\& cadmium. J. Environ. Pathol. Toxicol. Oncol., 19(3): $201-213$.

Swartwout, G. M. (2002) : Cataract Prevention \& Reversal. Mirrored with permission from http://www.wizardofeyez. Com/ cataract. Html. 8/5/2007.

Taylor, A.; Jacques, P. F. and Dorey, K. C. (1993) : Oxidation and aging Impact on vision. Curr. Eye. Res., 8 (2) : 150.

Vanloon, J. (1985) : Selected Method of Trace Metal Analysis: Biological and Environmental Samples. John Wiley \& Sons, New York, P.211 - 221.

Wong, W. Y.; Thomas, M. G.; Merkus, H. M. (2000) : Cigartte smoking and the risk of male factor subfertility: Minor association between cotinine in seminal plasma and semen morphology. Fertil., 74:930.

World Health Organization WHO (1998): The World Health Report: Life in the 21 st Century: a Vision for All; 47. Geneva, Switzerland. 


\title{
الكاد عيو م والرصاص فى عدسات و ثيتا مين جـ و هـ والبيتاكاروتيـن فى

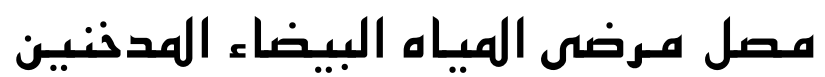

\author{
المشتركون فى البحث
}
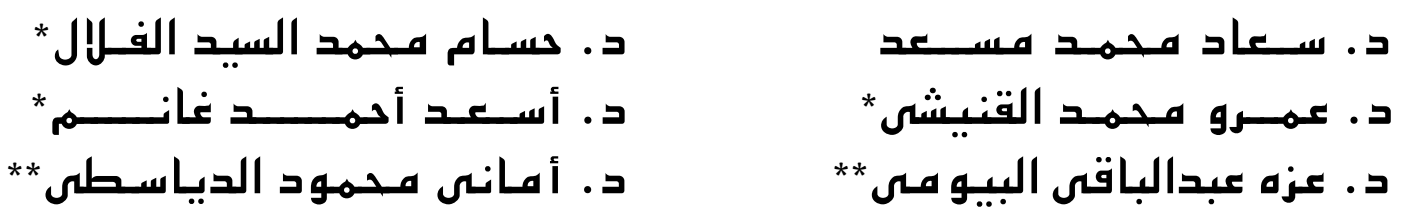

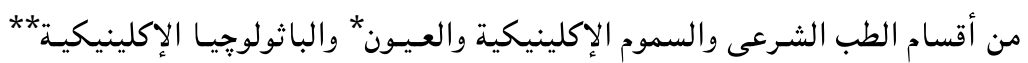

كلية الطب - جامعـة المنصـورة

تعتبر المياه البيضاء سبباً رئيسياً لنقص الإبصار وقد إزدادت الحالات المصابة بها نظراً لازدياد متوسط الأعمار، وحيث أنه من الممكن

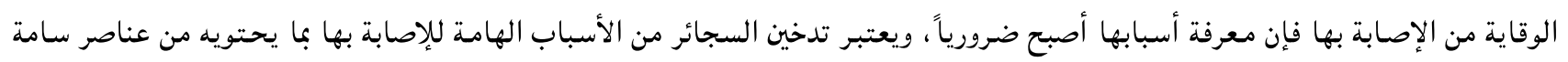

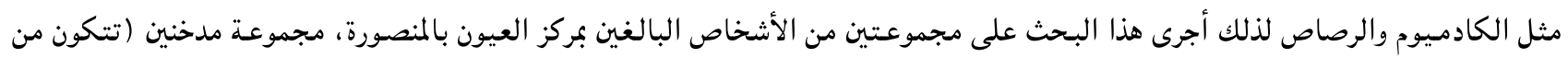

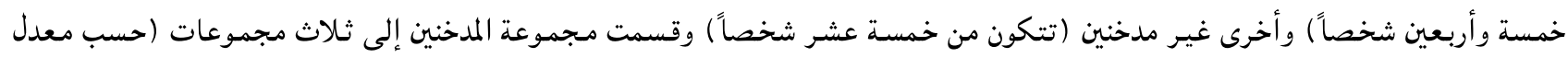

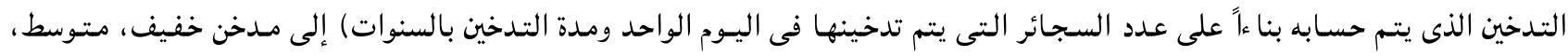

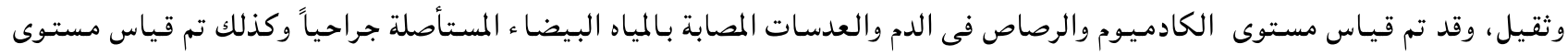
بعض مضادات الأكسدة مثل ثيتامين ج و هـ والبيتاكاروتين وقد أظهرت النتائج مايلى : زيادة ملحوظة فى تركيز الكادميوم فى دما ؛ وعدسات المدخنين عند مقارنتهم بغير المدخنين وخاصة ثقيلى التدخين، كما لوحظ زيادة ذات دلالة إحصائية عالية فى تركيز الرصاص فى دماء وعدسات المدخنين عند مقارنتهم بغير المدخنين. وبالنسبة لمضادات الأكسدة لوحظ نقص ذو دلالة إحصائية فى مستويات ثيتامين ج و هـ والبيتاكاروتين فى المدخنين عند مقارنتهم بغير

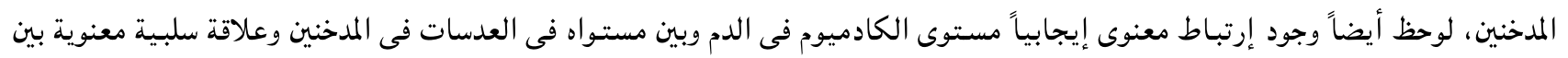
مستوى الكادميوم فى الدم ومستوى ثيتامينات ج و هـ والبيتاكاروتين فى المدخنين عند مقارنتهم بغير المدخنين. ومن هذا البحث نستنتج أن الكادمـيوم والرصاص الناتجين من تدخين السجائر لهم دوراً هاماً فى حدوث الميـاه البيضاء عن طريق إنتـاج

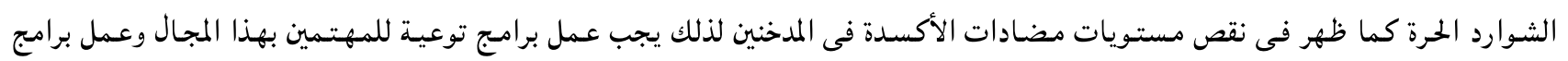

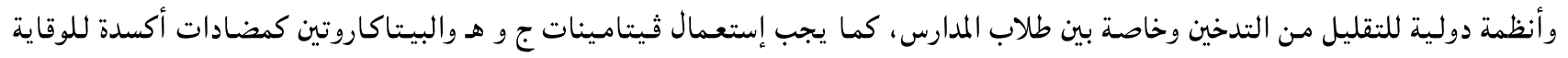
من المياه البيضاء والإبطاء من تأثيرها. 